Article

\title{
Development of cognitive strategies with digital games in non- formal education
}

\author{
Fernando Silvio Cavalcante Pimentel ${ }^{1, *}$, Larissa Torres da Silva ${ }^{2}$ and Maria Dolores Fortes Alves ${ }^{3}$ \\ 1 Federal University of Alagoas; prof.fernandoscp@gmail.com \\ 2 Federal University of Alagoas; larissa.trres@gmail.com \\ 3 Federal University of Alagoas; mdfortes@gmail.com \\ * Correspondence: prof.fernandoscp@gmail.com; Tel.: +55 82991075640
}

\begin{abstract}
This paper presents a case study analyzing which learning cognitive strategies are employed by students who play digital games in both in-school and out-of-school learning contexts. As a Case Study, it falls within the qualitative research category. The researcher integrated themselves to the subjects' learning facility for data-gathering, following all recommended ethical protocols for research involving underage subjects. The following data collection instruments were used: research diary, questionnaire, and interviews, conducted with teenagers who play digital games during formal learning activities. Analysis involved data-crossing and checking our data against existing studies and theories, as well as a cartographic production. Data indicates that digital games enhance student usage of cognitive strategies and favor competencies and abilities-based learning over formal learning contents.
\end{abstract}

Keywords: cognitive strategies; digital games; teaching; learning

\section{Introduction}

Nowadays, most people live in a digital universe. Teachers and students alike are often online, as digital media are a constant in the lives of children and young people, at school and elsewhere. Electronic games are one of various digital media and technologies routinely enjoyed by many [1]. Therefore, most children are born into a technological world and are progressively immersed in this universe, at once the products and the producers of our digital culture [2].

Although the development of this research was conducted before the COVID-19 pandemic, caused by SARS-CoV-2, the data analysis collaborates with the investigative field on digital technologies. Identified and declared a pandemic by the World Health Organization in March 2020, the disease has promoted social isolation as one of the effective ways in the quest to contain its advance. Such isolation has prevented people from living as they used to, and technologies are increasingly in evidence in the educational [3].

Digital Culture or cyberculture encompass the ways in which virtual spaces are used and appropriated by cultural subjects [4]. Pimentel [5] explains that by playing with digital technologies, digital culture children use those cultural artifacts to learn. Moreover, as Digital Technologies (DT) progress, the relevance of digital games has expanded beyond the sphere of entertainment and they are increasingly used in a variety of contexts, including new teaching practices.

We must regard Digital Game-Based Learning (DGBL) [6, 7] critically and analytically, and this involves rethinking our concepts of learning [8]. Our goal is to create diversified teaching strategies, rather than try to shoehorn DT into activities that can be developed without them. To that end, we must gain a better understanding of how digital 
games fit into Digital Culture, so that we may be better equipped to deal with them in classrooms and other settings (educational or not).

This study describes the results of an investigation conducted as part of a PIBIC Programa Institucional de Bolsas de Iniciação Científica [Brazil's National Scientific Initiation Scholarship Program] research. Our research question was: which cognitive strategies are promoted by incorporating digital games to learning contexts, both in-school and out-of-school?

Our main research goal was to analyze which cognitive learning strategies are employed by digital game players in both in-school and out-of-school learning contexts. Our research objectives were: ascertaining how digital games are used in learning processes that take place in educational contexts; understanding how digital games impact the digital culture paradigm shift, and determining how those games enhance the use of cognitive strategies in in-school and out-of-school learning contexts.

This paper presents the results of an empirical research conducted at a language school; data were checked against the theoretical framework underlying the research outline and development.

\section{Digital games in learning processes at educational settings}

Anastácio and Ramos [9] (pp. 160) define digital games as "a composite ludic activity that involves a series of actions and decisions limited by rules and by the game's universe, which result in a final condition". Such games are increasingly pervasive in children's lives, often even before they start school [5]. Games are gradually coming to be regarded as pedagogical resources for schoolteachers.

The use of digital games in educational contexts yields positive learning results, as verified by multiple studies $[6,7,8,9,10,11,12]$. It is fair to say that digital resources are widely used in our society. Both students and teachers are often online, and therefore DT has affected the ways in which we teach and learn [13].

When researching the relationship between education and digital games, many studies focus on incorporating them into the classroom context $[6,7,10,11,12,13$, 14], or researching the effects they can promote $[15,16]$. But the possibilities for research on digital games in education do not stop there. We can observe studies on teaching practices or on the strategies used by students when playing games, as well as on development and design, health implications, etc.

Moreover, students "were born into a digital culture that increasingly demands interactivity and participation in technology-mediated activities" [17] (pp. 4). Thus, using digital games in educational contexts acts as a draw for students, given that their interest might be piqued by the incorporation of devices and practices that they already use in other (more informal) settings.

Digital games enable teachers to discuss and problematize the many uses of technological devices such as tablets and smartphones, so ubiquitous in young peoples' lives [18]. That is but one possible contribution of digital games to learning, considering how technology shapes the world students live in.

The use of digital games in the classroom has the additional advantage of being a refreshing change from regular learning activities. According to Silva and Souza [10], students believe that teachers can facilitate learning by making their classes 'more dynamic', that is, less traditional and less centered on lecture-based lessons. Those scholars claim that incorporating DT to teaching practices helps students learn in simpler and more effective ways.

Digital games have a ludical component; Luckesi [19] (pp. 19) defines ludicity as "an internal state of well-being, joy, and fulfillment achieved by investing energy and time into an activity that can and should happen at any moment or stage in every human being's life". This is one of the main reasons why digital games are usually well-received by students: "children's interest in learning may manifest in different ways, many of which 
involve ludic and pleasant experiences. By combining ludicity and motivation, games can potentialize learning by small children, who are in constant development" [18] (pp. 221).

Games can make classes lighter, facilitate understanding and increase student interest, thus developing learning and thinking skills, aside from promoting curiosity and interest for the unknown [13].

Digital games help develop several competencies, such as problem-solving, creating algorithms, understanding mathematical concepts and its abstract notation system, and logical-mathematical thinking, aside from promoting learning of matters pertaining to various areas, such as economics, politics, ethics, environmental sustainability, etc. Therefore, digital games may be used for multidisciplinary, interdisciplinary and transdisciplinary learning involving a wide variety of topics, including but not limited to the ones listed above.

Teachers may use existing digital games with their students, and also propose that students build their own games. Thus, digital games "may enhance the development of knowledges and abilities, interaction, intersubjectivity, autonomous thinking and transcendence, furthering a student's critical consciousness" [19] (pp. 2). That is owed to how games demand that students research and learn about something, thereby pushing them to search for new information; this process causes students to become more knowledgeable and assume more active roles in the production of their own knowledge.

However, we must remember that "it is not enough to employ computational resources; instead, they must be fully integrated to teaching practices" [20] (pp. 9). One must not simply bring digital games into the classroom, for the true goal is the student's learning and this requires integrating DT into the school's Political Pedagogic Project (PPP), as Silva and Souza [14] remind us.

Therefore, despite their many verified contributions to learning, using digital games at school is no simple matter. As pointed out by Müller and Cruz [1], many schools lack the required digital resources (technological infrastructure). There are also gaps in teacher education and digital literacy; "teachers and students use digital media in their social lives, but at school those resources must be used with educational intent, properly addressed in pedagogical projects" [13] (pp. 2).

This calls for action in the initial education and professional development of teachers, most of whom have trouble incorporating media into their teaching practices despite using it regularly in their personal lives [1].

In addition, there is a limited number of digital games fit for educational use; many have very little pedagogic applicability, while others that are more specifically learningoriented lack technical quality, with sub-par interfaces, image quality, playability and interactivity [17].

\section{Cognitive strategies in $\mathrm{K}-12$ education}

Given the ubiquity of DT in today's society, digital media can be used to develop learning strategies [21]. These technologies enable us to access vast amounts of information, which is often presented in a constant, disordered, and dispersed manner [22]. This veritable informational tangle does not ensure that new knowledges are gained or enhanced simply upon being accessed, and thus we must employ strategies to ensure learning. Alves [23] defines learning strategies as actions that combine thinking, reason, emotion, intuition, and multidimensional ways to interact with information. This means that strategies allow us to deal with uncertainty and to mind ecology of action: when an action escapes us, it spreads beyond our control.

Learning strategies are defined by Silva [21] (pp. 24) as "tools employed by learning subjects to best store information and retrieve it as efficiently as possible when needed"; thus, they can benefit students' learning experiences at school and elsewhere. 
We must also consider that digital games open up new possibilities in terms of teaching and learning, which may allow us to reach people who favor different learning modalities, as well as build diverse learning scenarios and engage in learning that is interconnected, intersectional, interdependent, unique, and valid for each person, including their virtual and in-person relationships with others [24].

Let us begin by looking at Silva's [21] classification of learning strategies into cognitive and metacognitive ones. Darroz, Trevisan and Rosa [25] (pp. 97) define metacognitive strategies as those pertaining to "learning how to learn, [...] they are engaged when the subject identifies the best way to solve a problem-situation". In Pimentel's [5] words, those strategies are used to manage and control learning contexts.

This study focuses on cognitive learning strategies, the ones "focused on primary or basic learning [...] they can be further classified into rehearsal, production and organization strategies" [5] (pp. 89). They allow us to perform an initial structuration of knowledge and are mostly employed upon first contact with a new topic. According to Boruchovitch [26], cognitive strategies aim at specific learning and employ one or more strategies, such as highlighting and note-taking.

That cognitive strategies promote knowledge and have to do with performing tasks; they are "among the most commonly used strategies when it comes to gaining knowledge through organization and memory. However, most students employ those strategies mechanically" [25] (pp. 97). In other words, this sort of strategy is connected to mechanical learning and seldom promotes reflection about the act of learning in itself. The main goal would be storing information.

Cognitive strategies and their uses in formal educational contexts, but not limited to them, are systematized in Table 1.

Table 1. Cognitive Strategies and their actions

\begin{tabular}{cc}
\hline Strategies & Actions \\
\hline Rehearsal & Repeating keywords out loud \\
Repeating keywords in writing \\
Highlight portions of a text \\
Emphasizing portions of a text \\
Taking notes \\
Rewriting \\
Summarizing \\
Paraphrasing \\
Taking notes about one's own understanding of the topic \\
Creating rhymes \\
Creating abbreviations \\
Creating keywords \\
Creating analogies \\
Creating questions about a topic \\
Answering questions about a topic \\
Proposing categories \\
Creating conceptual networks \\
Making mind-maps or conceptual maps \\
\end{tabular}

Source: Silva [21].

We can infer from Table 1 that cognitive strategies can be implemented using a variety of artifacts, DT included. According to Costa [27] (pp. 29), "the heart of the matter is not technology in itself, but rather how we regard that technology, using it first and 
foremost as a cognitive learning strategy". This claim implies that we must seek to understand DT as artifacts whose full integration to classrooms demand that we rethink the social role of schools, syllabuses, and teacher education.

Pimentel [5] says that rehearsal strategies involve the repetition of keywords (either out loud or in writing), emphasizing key text portions, and also note-taking.

Production strategies include rewriting, summarizing, paraphrasing, taking notes about one's personal comprehension of a text, abbreviations, keywords, analogies, as well as creating and answering questions about a topic. In other words, while rehearsal strategies emphasize repeating newly-learned contents, production strategies function by associating the new information to previous knowledge. Organization strategies form categories and create conceptual networks and maps, thus structuring the information one intends to learn [5]. This is very common in K-12 Education.

Based upon that, we may infer that "teachers must use different strategies during class, creating various possibilities and allowing more students to effectively learn" [5] (pp. 88), given that each student responds better to a different learning strategy. For students of English as a Foreign Language (as well as other languages), cognitive learning strategies can contribute significantly to learning insofar as they lead students to practice - performing repetitions, taking notes, creating analogies, etc.

Pimentel [5] stresses that schools are engaged in developing cognitive strategies and even in incorporating DT into it, but children and teens visibly tend to use DT for more than just rehearsal, production, and organization strategies. Our expectation is that by using DT as cognitive tools, students will have the opportunity to form and confirm hypotheses and in so doing produce their own knowledge [28].

Interaction with digital games promotes a shift in knowledge, as the experience of playing mobilizes existing knowledge and develops new knowledge [29]. Digital gamebased learning theory understands that games require players to exercise a directed cognitive skill repeatedly in a variety of contexts and at increasingly challenging levels. Interaction with games can create different processing in the brain, engaging the learner in cognitive processing, not always consciously.

\section{Methodology}

Our research falls into the qualitative category seen as how we worked with subjective aspects, trying to ascertain non-explicit or even unconscious motivations, and seeking to build perceptions and understanding about the general nature of the researched topic, with room for interpretation. The best fit for our analytical approach and data collection particularities was the Case Study [30], combined with Cartography procedures, which enable the researcher "to map psycho-social landscapes, to dive into a geography of affects, movement, and intensity" [31]. In order to draw such maps, the researcher has immersed themselves into the field and therefore this investigation has yielded more than conclusive results, seen as how the entire process was of the utmost relevance.

Data collection involved students of a language school in the city of Maceió, AL, Brazil. First, we tried reaching out to a few Maceió public schools, but none of them met our research requirements. We tried private schools next, to no avail. In the end, a language school was the best fit for our research.

We used three research instruments: questionnaire, participant observation, and interviews, in that order. By integrating ourselves into the subjects' learning context, observing and documenting (taking notes), we were able to produce an accurate description of what happened, which formed the basis for our analysis. In addition, data collection and analysis allowed us to describe reality. Data evaluation involved inter-pretation, sequential analysis, and coding.

The questionnaire (Table 2, 3 and 4) we used was developed and validated in previous research by Pimentel [5], who discussed children's learning in the digital culture. This instrument is a self-administered type that addresses the questions related to the aim 
of this study: to analyze what cognitive learning strategies are mobilized through digital games in school and out-of-school contexts. It is developed in the form of a self-report, when the respondent must fill it out himself.

Table 2. Questionnaire - Section

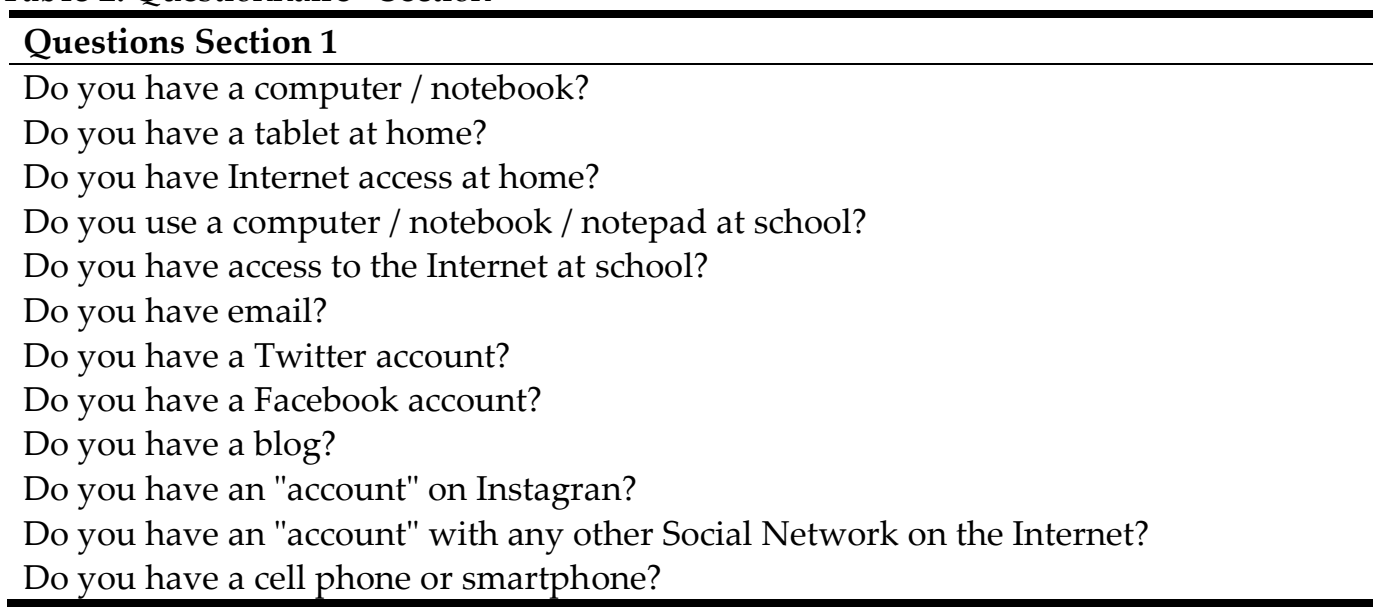

It should be noted that this second phase of the instrument aims to identify the predominant profiles presented on a five-point Likert-type scale (Table 3). Thus, there are no answers that indicate right/wrong or better/worse patterns.

Table 3. Questionnaire Section 2

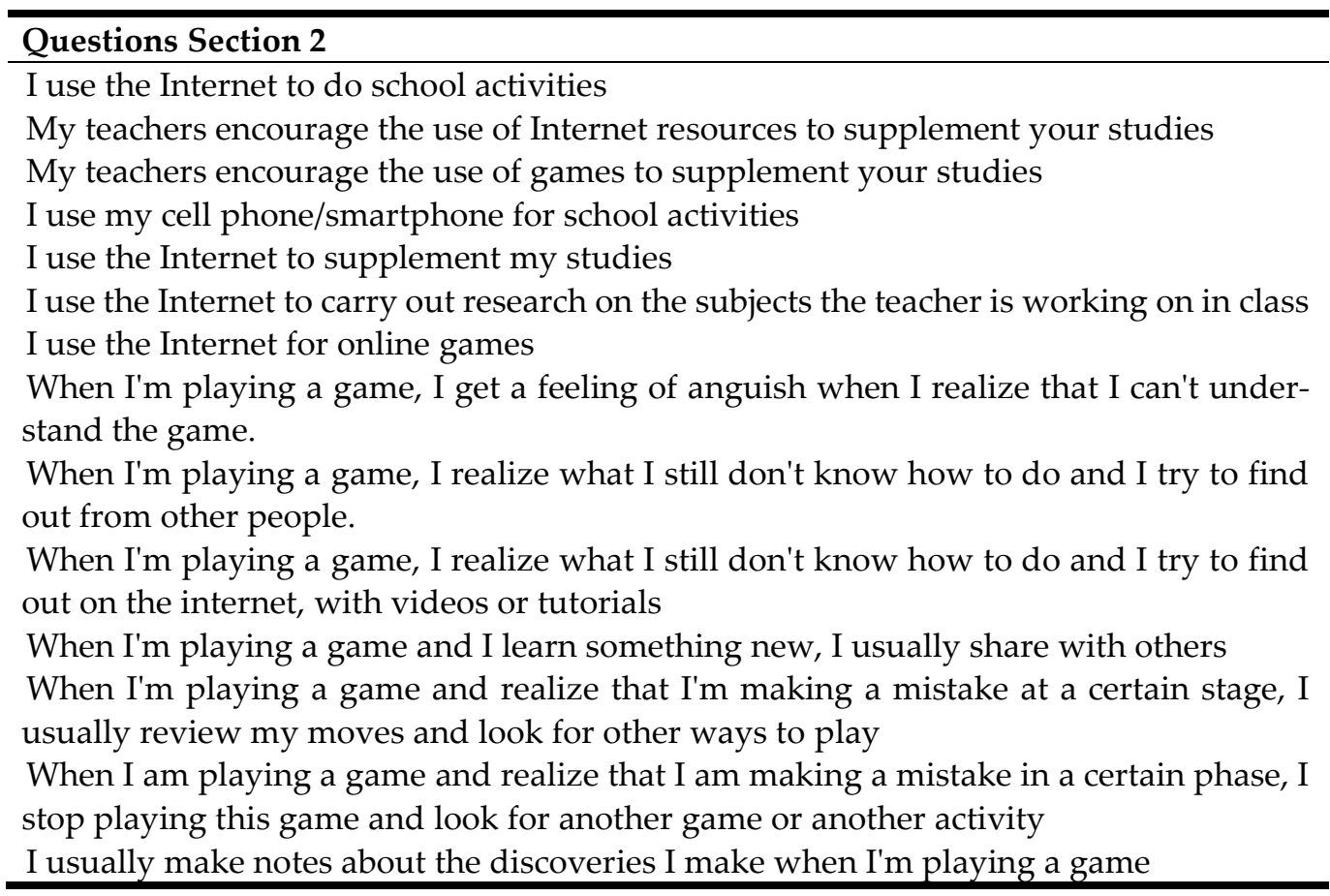

The third section of the questionnaire consisted of three open-ended questions, allowing the participating subjects freedom of expression (Table 4).

Table 4. Questionnaire - Section 3

Questions Section 3
If you are playing online in another language, what do you do to understand the game?
When you are playing online with people of another language, what do you do to com-
municate?


What do you do to learn how to play a game?

For the interview we used open questions, elaborated from the analysis of the answers to the questionnaire. The main objective of the interview was to observe if the participants had the understanding that they were learning something when they played.

This research was approved by the Ethics Committee of the University. The inclusion criteria were: teenagers aged between 12 and 15 who had signed our Term of Agreement and whose parents had signed the Free and Informed Consent Term (FICT); exclusion criteria were: teenagers who did not attend the language school where the research took place and who did not use digital games on a daily basis.

\section{Results and discussion}

The class where the research was carried out was small, in relation to the number of students. We encountered some difficulties in the development of the research, since the students were teenagers and did not understand well the commitment, they should have in forwarding the consent form that their parents or guardians should sign. Without this document, their participation was not possible. Another difficulty is in the adolescents' attendance to this type of course/class. Our sample should have had more students, however, we only had two participants. Our research subjects were two teenage girls aged 14 and 15, respectively attending the final year of Middle School and the second year of High School in the Brazilian system.

After the consent steps were taken, following the ethical procedures, we proceeded to the data collection with the two students. Section 1 of the questionnaire assessed participants' relationships to Digital Culture, determining whether they owned and used digital artifacts and social media.

Both subjects have a computer or notebook and Internet access at home, and one of them also mentioned owning a tablet. Only one subject answered about Internet access at her school, stating that there was none. The questionnaire also revealed that both teenagers are online for an average of 6-10 hours a week. These data correspond to a period before the Covid-19 pandemic. If the same research were conducted at this time (2020 or 2021), the data would be different.

Both subjects own smartphones. On the topic of social media, both are active Instagram users and only one of them also has Twitter and Facebook accounts. Both have email accounts and neither keeps a blog. The data are in line with both CGI.br logs and Pimentel's [5] research, allowing us to classify both teenagers as Digital Culture members on account of owning digital artifacts and using them in everyday life. These devices are used more by teenagers than computers or laptops for their routine entertainment or learning activities.

Section 2 of the questionnaire employed a Likert scale to identify how the subjects use digital artifacts and the Internet as learning strategies. Question 2.1 was about using the Internet for school assignments; one subject said she rarely did that, and the other that she sometimes did. This indicates that both are still unfamiliar with the learning potential of the Internet and digital artifacts; their usage of those technologies is still centered on entertainment.

When asked whether their teachers encouraged students to use Internet resources as study tools, both answered affirmatively. They stated that their teachers constantly encouraged them to do that, disavowing their answers to Question 2.1. It should be noted that when asked whether their teachers encourage the use of digital games as study tools, both subjects stated that that never occurs. This is an example of resistance to incorporating digital games in this particular context. Despite several researches on how games can contribute, there is a gap between teachers' training to incorporate digital technologies in their classes. 
However, both subjects reported sometimes using their cellphones/smartphones for school assignments and tasks, as well as researching topics addressed in the classroom, even though one of them had previously stated that she rarely used the Internet as a study tool. Conversely, the teenagers declared that they always use the Internet to play online.

On that topic, both said that while playing they never feel troubled upon realizing that they cannot understand the game they are playing. One subject said that when she got stuck on a game obstacle, she often tried to look up videos or tutorials online, while the other subject said she rarely used those resources. Likewise, one subject stated often talking to other people for that end, while the other subject said she sometimes did that.

When asked whether they share with others new knowledges gained when playing a game, one subject answered 'rarely' and the other 'often'.

In the same questionnaire section, when asked about whether they go over their moves and try alternatives upon realizing that they are unable to complete a game level, one subject answered 'often', which signals the use of Silva's [21] production cognitive strategies, such as analyzing/reviewing moves.

The other subject answered 'never' to the same question. When asked about whether a string of failures at a game causes them to stop playing it and try a new one or engage in another activity, they provided similar answers: 'never' and 'rarely'.

The final question in Section 2 inquired whether they are in the habit of writing down discoveries made while they play, and both subjects answered 'never'.

The last section of the questionnaire comprised questions about their gaming experience. Question 3.1 was about the tools and strategies employed to understand a game in a foreign language while playing online. One subject reported using a translator, while the other said she tried to infer and interpret. Asked about their experience playing online with speakers of other languages, one subject reported using the translator or her previous knowledge to communicate, while the other reported managing reasonably well, depending on the language spoken by her fellow players. Those answers involve a) rehearsal strategies [16], in that words tend to be used repeatedly in a game and thus to be read/said a number of times, and b) production strategies such as analogies, when the subjects associate new knowledges to existing ones.

Lastly, when asked about how did they learn how to play a game, both subjects gave similar answers: they reported playing it over and over again, that is, using repetition as a cognitive strategy [21].

In addition to the questionnaire, we have also interviewed the subjects in order to obtain data that might not be obtained by observation and the questionnaire. We began by asking the subjects whether they usually played any games. Both answered affirmatively: one plays Paladdinos and Minecraft, and the other plays Free Fire.

Next, we asked whether they believed one can learn things by playing digital games. Both teenagers agreed that yes, digital games can help a person learn new languages while communicating with other people, even foreigners. According to Bastos and Amorim [32], talking to native speakers is also a cognitive learning strategy in the study of a foreign language. This confirms a connection between these strategies and out-of-school learning.

When asked whether they had ever learned anything while playing games, both subjects answered 'new languages'. When asked if they had learned anything else, both said 'no'. This answer seems to be fundamental for us to think about strategies for using games in the classroom, or in the out-of-school context. We understand that teachers need to understand how and what can be learned from games, and at the same time, teachers need to make it clear to their students what they can learn, or what they can learn from games. This involves revisiting the teacher training curriculum.

When asked about where they usually play, one subject said that she played at home and during her English classes, while the other said that she only played at home, even though both of them do play during English classes (as seen during participant observation).

The last question of the interview tried to ascertain whether any of the subjects' schoolteachers use digital games during classes. One subject answered affirmatively and 
explained that her English teacher at school uses a school app, while the other subject said 'no'.

The interview and the questionnaire were complemented by observation: the researcher sat in during the participants' language classes and witnessed them play games brought by their teacher, which allowed us to observe them employ certain cognitive strategies. Both students used production strategies (analogies): while playing, they associated new information to previous knowledge. Certain class activities and dynamics also involved rehearsal strategies, such as repeating keywords (mostly out loud, but also in writing). This particular strategy is especially common in foreign language classes, where students are often told to repeat words and sentences, and to write them down.

Our observation has also revealed that the teenagers are more involved, more participative, and less absentminded in class when games are used. Digital games seem to increase their curiosity and willingness to learn, especially when they lose; that is likely owed to how they try to understand what caused them to lose, so that they can avoid repeating the same mistake. Thus, any misses in the game caused them to pay greater attention to the teacher and to try to recall what they had previously studied about the contents addressed by the game.

We have also observed that the subjects showed greater interest in game topics related to their everyday lives. The class often played quizzes in groups, in which the groups scored points by answering correctly and before their competitors. In other words, if two groups answered the same question correctly, the group that answered first would score more points for its shorter response time. When playing these quizzes, the subjects were anxious to answer soon and were sad and upset when they missed a question or were not the first group to answer it.

\section{Conclusions}

The bibliographical review has taught us that DT developments have impacts on teaching and learning. Nowadays, it is possible to employ learning strategies via digital media. Using these teaching-learning strategies can be helpful to students, as confirmed by our research.

The collected data have also confirmed our research objectives, especially regarding how digital games are used in learning processes at educational contexts - in this case, to begin a class, to introduce and reinforce contents, and to confirm learning. Therefore, the use of digital games in educational contexts produces verifiable changes in the digital culture paradigm as these contexts adapt to DT developments and to better serve their students, who are constantly immersed in a digital world.

The research objective centered on whether cognitive strategies in both in-school and out-of-school learning contexts could be bolstered with the use of digital games was also confirmed. Although the research subjects did not seem aware of it, their testimonies allowed us to ascertain that using digital games (at school or not) does help them learn and that the games are indeed used as learning strategies, even if that is not deliberate on their part.

As presented, in the relationship of the data collected through the three instruments (questionnaire, interview, and observation), digital games are promoters of learning, even when those who play are not aware of how playing is promoting cognitive change. The cognitive strategies indicated in the theoretical framework are visible in the answers and in the triangulation of the data.

Cognitive rehearsal strategies (repeat key words aloud, repeat key words in writing, underline part of a text, highlight part of a text, make notes), elaboration strategies (rewrite, summarize, make notes on one's own understanding of the subject, make analogies, answer quiz on a subject) and organization strategies were not as evident in the course of the research. Not all strategies had a direct relationship to digital games. This leads us to 
consider a new hypothesis: if teachers are prepared to intentionally use games, there will be a change in the development and use of cognitive strategies.

Also, in the current context of the pandemic, when social isolation has led to a greater use of digital technologies to minimize the damage of children being away from school, it is necessary to undertake empirical research that can analyze this phenomenon, opening space for new understandings of how technologies, specifically games, can promote cognition. Here is an open invitation to rethink our teaching and learning actions and strategies.

\section{Limits of the study}

The greatest difficulties met during our research were related to data-gathering. Our initial plan was to study public school students in their final year of Middle School whose teachers used digital games in class; however, we were unable to find any public schools that met those criteria. Next, we tried contacting private schools in hopes of finding any that used digital games in class, but once more came up empty. That led us to adapt our plans and collect our data at an English as a Foreign Language school, searching for a class with students aged between 12 and 15 (the average age for students in the final year of Middle School).

This meant that only part of the students at the class indicated by the school coordinator met our research criteria. Moreover, the class had only a small number of students and not all of them matched the age of our target demographic. Lastly, the greatest obstacle involved the Term of Agreement and the Term of Free and Informed Consent: some students forgot to bring in their signed terms, and some parents did not allow their children to participate in the study.

In view of the aforementioned difficulties, we believe that further research must be done on the subject. For instance, we should be looking into why teachers do not use digital games in class, even though it would bolster learning, as verified in this study and described by many scholars. That could contribute to promoting autonomous thinking and new ways of producing knowledge drawing from the experiences of multisensory, multidimensional subjects interacting with virtual and/or real environments.

Author Contributions: Conceptualization, F.S.C.P; L.T.S. and M.D.F.A; Data curation, L.T.S.; Formal analysis, L.T.S. and F.S.C.P.; Research, L.T.S and F.S.C.P.; Methodology, L.T.S and F.S.C.P.; Project management, F.S.C.P.; Writing - original draft, L.T.S.; Writing - proofreading and editing, F.S.C.P. and M.D.F.A. All authors have read and agreed to the published publication of the manuscript.

Funding: Funding: This research was funded by the National Council for Scientific and Technological Development (CNPq - Brazil) with the provision of a scientific initiation scholarship for the second author.

Acknowledgments: Acknowledgments: The authors thank the reviewers for their insightful comments, as well as thanking the CNA Ponta Verde and the National Council for Scientific and Technological Development (CNPq - Brazil) for the grant of the scientific initiation scholarship.

Conflicts of Interest: The authors declare no conflict of interest. The funders had no role in the design of the study; in the collection, analyses, or interpretation of data; in the writing of the manuscript, or in the decision to publish the results.

\section{References}

1. Müller, A. C. N. G.; Cruz, D. M. Formação docente para inclusão de games na educação básica: relato de uma experiência. Obra Digital Revista de Comunicação. n. 10, 2016. p. 33-50. 
2. Knaul, A. P.; Ribeiro, S. P.; Schnell, R. F.; Ramos, D. K. Games educativos em contextos escolares: características e contribuições. In: Ramos, D. K.; Cruz, D. M. (org). Games em contextos educacionais. Curitiba: Editora CRV, 2018.

3. Pimentel, F. S. C.; Silva Júnior, L. C.; Cardoso, O. Ações e estratégias educacionais em tempo de pandemia. Interfaces Científicas - Educação, v. 10, n. 1, p. 93-109, 6 set. 2020. Available at: https://periodicos.set.edu.br/educacao/article/view/8987

4. Lucena, S. Culturas digitais e tecnologias móveis na educação. Educar em revista. n. 59, 2016. p. 277-290.

5. Pimentel, F. S. C. A aprendizagem das crianças na cultura digital. 2ª ed. ver e ampl. Maceió: Edufal, 2017.

6. Van Eck, R. Digital game-based learning: It's not just the digital natives who are restless. EDUCAUSE review, v. 41, n. 2, p. 16, 2006. Available at: https://er.educause.edu/articles/2006/1/digital-gamebased-learning-its-not-just-the-digital-nativeswho-are-restless

7. Van Eck, R. Digital game-based learning: Still restless, after all these years. EDUCAUSE review, v. 50, n. 6, p. $13,2015$. Available at: https://er.educause.edu/articles/2015/10/digital-game-based-learning-still-restless-after-all-these-years

8. Ramos, D. K.; Cruz, D. M. A tipologia de conteúdos de aprendizagem nos games: o que podemos aprender? In: Ramos, D. K.; Cruz, D. M. (org). Games em contextos educacionais. Curitiba: Editora CRV, 2018.

9. Anastácio, B. S.; Ramos, D. K. O uso do jogo digital “saga dos conselhos" na educação a distância: uma experiência lúdica. In: Ramos, D. K.; Cruz, D. M. (org). Games em contextos educacionais. Curitiba: Editora CRV, 2018.

10. Annetta, L. A. Video games in education: Why they should be used and how they are being used. Theory into practice, v. 47 , n. 3, p. 229-239, 2008.

11. Savi, R.; Ulbricht, V. Jogos digitais educacionais: benefícios e desafios. RENOTE-Revista Novas Tecnologias na Educação, v. 6, n. 1, 2008.

12. Barba-Martín, R. A. et al. The application of the teaching games for understanding in physical education. Systematic review of the last six years. International journal of environmental research and public health, v. 17, n. 9, p. 3330, 2020.

13. Pereira, C. S.; Campos, M. A. Os estudantes surdos e os games. In: Barbosa, M. S. et al. Educação aberta e flexível: caminhos para aprendizagem significativa. Vitória da Conquista: Editora EGBA, 2016.

14. Silva, E. B.; Souza, A. W. M. Autoria de games em geografia. In: Barbosa, M. S. S. et al. Educação aberta e flexível: caminhos para aprendizagem significativa. Vitória da Conquista: Editora EGBA, 2016.

15. Zhonggen, Y. Uma meta-análise do uso de serious games na educação ao longo de uma década. International Journal of Computer Games Technology, v. 2019, 2019.

16. Mayer, R. E. Computer games in education. Annual review of psychology, v. 70, p. 531-549, 2019.

17. Alves, L. Relações entre os jogos digitais e aprendizagem: delineando percurso. Educação, Formação E Tecnologias. v. 1, n. 2 , 2008, p. 3-10.

18. Ramos, D. K.; Anastácio, B. S. Habilidades cognitivas e o uso de games na escola: a percepção das crianças. Educação Unisinos. Florianópolis, v. 22, n. 2, 2018. p.214-223.

1. Luckesi, C. Ludicidade e formação do educador. Entreideias. v. 3, n. 2, 2014. p. 13-23.

19. Pereira, A. B. C.; Silva, F. S. C.; Piconez, S. C. B.; Zimmer, J. M. Games no desenvolvimento de conceitos matemáticos sob perspectiva BYOD e abordagem m-Learning na escola pública. In: Congresso Brasileiro de Informática na Educação, 5. 2016, São Paulo. Anais... São Paulo: [s.i.], p. 01-10.

20. Marinho, F. C. V.; Struchiner, M. Estudantes do ensino básico como desenvolvedores de games. Em Teia. V.4, n.3, 2013. p. 1-25.

21. Silva, L. Estilos e estratégias de aprendizagem de estudantes universitários. 2012. Dissertação (Mestrado) - Programa de PósGraduação em Psicologia. Área de Concentração: Psicologia Escolar e do Desenvolvimento Humano) - Universidade de São Paulo, São Paulo.

22. Beluce, A. C.; Oliveira, T. S.; Oliveira, G. T. As tecnologias digitais e as estratégias de aprendizagem observadas pelos professores. In: Congresso do Programa de Pós-Graduação em Psicologia da UEL. 1., 2018, Londrina. Anais... Londrina: [s.i.], p. 275-280.

23. Alves, M. D. F. Práticas de aprendizagem integradoras e inclusivas: autoconhecimento e motivação. Rio de Janeiro: WAK Editora, 2016.

24. Alves, M. D. F; Viana, M. A. P.; Santos, V. L. P. Docência e estratégias de aprendizagem integradoras no ambiente virtual de Ensino e aprendizagem in: professores universitários em (trans)formação. (des)construindo saberes e reinventado práticas. Maceió: Edufal, 2017.

25. Darroz, L. M.; Trevisan, T. L.; Rosa, C. T. W. Estratégias de aprendizagem: caminhos para o sucesso escolar. Amazônia: Revista de Educação em Ciências e Matemáticas, [S.1.], v. 14, n. 29, 2018. p. 93-109, jul. Disponível em: $<$ https://periodicos.ufpa.br/index.php/revistaamazonia/article/view/5473>.

26. Boruchovitch, E. Aprender a aprender: propostas de intervenção em estratégias de aprendizagem. ETD - Educação Temática Digital, v. 8, n. 2, 2007. p. 156-167.

27. Costa, F. A. O que justifica o fraco uso dos computadores na escola? Faculdade de Psicologia e Ciências da Educação da Universidade de Lisboa. Polifonia, Lisboa, Edições Colibri, n.. 7, 2004, pp. 19-32.

28. Silva, P. F. O uso das Tecnologias Digitais como Ferramentas Cognitivas. Novas tecnologias na educação. v. 17, n. 2, 2019. p. 76-86,

29. Mayer, R. E. Cognitive Foundation of Game-Based Learning. In: Plass, J. L.; Mayer, R. E.; Homer, B. D. (Ed.). Handbook of Game-Based Learning. Mit Press, 2019.

30. Yin, R. K. Estudo de caso: planejamento e métodos. Porto Alegre: Bookman, 2001. 
31. Martines, W. R. V.; Machado, A. L. \& Colvero, L. A. A Cartografia Como Inovação Metodológica Na Pesquisa Em Saúde. Tempus: Actas de Saúde Coletiva, Brasília, v. 2, n. 7, 2013. p. 203-211, set.

32. Bastos, I. F.; Amorin, S. S. Estratégias de aprendizagem utilizadas pelo professor de língua inglesa no aperfeiçoamento profissional. In: Simpósio Internacional de Educação e Comunicação, 9., 2018, Aracaju. Anais... Aracaju: [s.i.], (2018). p. 01-15. 